Wood, Margaret ORCID:

https://orcid.org/0000-0001-5067-1978 and Su, Feng (2019)

Parents as "stakeholders" and their conceptions of teaching excellence in English higher education. International Journal of Comparative Education and Development, 21 (2). pp. 99-111.

Downloaded from: http://ray.yorksj.ac.uk/id/eprint/3876/

The version presented here may differ from the published version or version of record. If you intend to cite from the work you are advised to consult the publisher's version: http://dx.doi.org/10.1108/IJCED-05-2018-0010

Research at York St John (RaY) is an institutional repository. It supports the principles of open access by making the research outputs of the University available in digital form. Copyright of the items stored in RaY reside with the authors and/or other copyright owners. Users may access full text items free of charge, and may download a copy for private study or non-commercial research. For further reuse terms, see licence terms governing individual outputs. Institutional Repository Policy Statement

\title{
RaY
}

Research at the University of York St John

For more information please contact RaY at ray@yorksj.ac.uk 


\section{Parents as 'stakeholders' and their conceptions of teaching excellence in higher education in England}

\section{Abstract}

\section{Purpose}

The purpose of the study was to explore parents as 'stakeholders' in higher education in England and how they perceive teaching excellence.

\section{Design/methodology/approach}

The study adopted a qualitative research design using an interpretative approach which aimed to develop understandings of parents' perspectives as higher education 'stakeholders'. The empirical data was gathered via focus group interviews and an online survey with twenty-four participants in the UK.

\section{Findings}

This study found that the majority of parents wished to be treated as an important stakeholder group in higher education. Parent participants perceived that teaching excellence could be evidenced through indicators and measures, for example, the design and delivery of the courses, progress measures, contact hours, speed of return of marked work, graduate employability and so on. They also saw value and significance in the students' exposure to ideas and perspectives not previously experienced, in zeal and passion in the teaching, and in an academically nurturing, understanding and supportive pedagogical relationship between academic and student.

\section{Originality/value}

This study uncovered some apparent tensions, contradictions and challenges for parents as stakeholders in higher education, for example, in reconciling the co-existence of their desire to be involved and engaged with scope for students to be formed as independent young adults. Parents' desire to measure teaching excellence is also compounded by their concern that excellent teaching is thereby reduced to a box-ticking exercise. This study has implications for higher education institutions wishing to engage parents as a stakeholder group in a meaningful way.

Keywords: university, teaching excellence, English higher education, parents as 'stakeholders' 
Your children are not your children.

They are the sons and daughters of Life's longing for itself.

They come through you but not from you,

And though they are with you yet they belong not to you.

'On Children' by Kahlil Gibran (2016:33)

This paper reports the findings of a study of parents as 'stakeholders' in higher education in England and how they perceive teaching excellence. To speak of 'stakeholders' may not seem out of place in higher education discourse today, the inherent assumptions suggestive of a conception of higher education in economic terms. The maxim 'if markets work 'properly', consumer interest is maximised: real competition will 'drive up quality' and 'drive down prices' (Collini, 2017:158) is apparent in government policy in England proceeding from an ideological conviction that:

Competition between providers in any market incentivises them to raise their game, offering consumers a greater choice of more innovative and better quality products and services at lower cost. (Department for Business, Innovation \& Skills, 2016, page 8 para.7).

Unsurprisingly therefore it seems that the language of 'stakeholder' is often employed now in higher education. Operating in a competitive environment it appears to make good business sense for higher education providers to know their stakeholders and their needs. Factors identified by Veiga et al., 2015 in Magalhães et. al, 2018, which include the erosion of academic self-governance and the declining power of academics in university decision-making, together with an increased role for external stakeholders in the governance of higher education are referred to by Magalhães et al. (2018:738) as 'the main ingredients of boardism' (Veiga, Magalhães and Amaral, 2015 in Magalhães et. al. 2018:738). This has significance as:

Under the framework of governance reforms, and influenced by boardism, the role of external stakeholders has been further enhanced, bringing forward to higher education institutions both the sensitivity to the external environment and the managerial and decision-making practices coming from the non-academic world. (Magalhães et. al. 2018:738)

It may be considered unusual to refer to parents as 'stakeholders' in higher education and in the literature they are not always included amongst the stakeholder groups mentioned in relation to the university. The work of Leveille is drawn on in this paper because it includes parents amongst the 'people who influence stakeholders or customers' (Leveille, 2006:155) and studies have identified the role of parents as one influence on how students choose college and university 
(Hazelkorn, 2015:138) and furthermore 'students (and their parents) have become savvy consumers' (Santiago et. al., 2008 in Hazelkorn, 2015:6).

Against this backdrop we examine teaching excellence and what sense parents, often these days having contributed financially towards the costs of their children's university education, make of this idea. The concern of our research, reported in this paper, was with the development of understandings of parents' sense-making when it comes to teaching excellence in higher education - what is teaching excellence, how should it be measured and what evidence might be used?

This paper refers primarily to England as most of our participants were from England. One participant was from Northern Ireland. Higher Education is a devolved matter in Scotland, Wales and Northern Ireland (DfBIS, 2011). The funding context referred to in this paper is that in England. There are two types of costs for higher education: tuition fees and living costs. Students can apply for a tuition fee loan to cover all or part of their fees (typically $£ 9,250$ per year at the current time) and a maintenance loan to help towards the costs of living expenses (Universities and Colleges Admissions Service, 2018).

\section{Parents as 'stakeholders' in higher education}

We recognise that some people are brought up by adults other than their parents and in using the term 'parents' we include parents and carers but have chosen to opt for 'parents' as a less cumbersome, shorthand form. Whilst recognising that university students are young adults, we have also referred to 'children' rather than sons or daughters or the oxymoron 'adult-children' or even 'offspring', because parent participants in our study referred to their own 'children' rather than their 'young people' and some had sons or daughters about to go to university and who were therefore still of school age. We also recognise that some university students are parents themselves, however, in this study we refer to students who are parented rather than students who may be acting themselves in a parenting role.

There is a well-established literature about parental involvement in schools. It may be questioned why parents should continue to be involved and considered to have a stake when on reaching the post-compulsory stage of education, young people are deemed to have entered adulthood. Having left the compulsory phase of education, the relationship of parents to university is very different to the previous parental role and relationship with the school, which acted in loco parentis. However, on the other hand, transition into adulthood today can be a protracted process in a challenging economic climate. It is interesting to note the increase in young adults now living with their parents than was the case a decade ago, as reported by the Intergenerational Commission (2018:15). The concept of 'emerging adulthood' (Arnett, 2015) is characterised by 'longer and more widespread education, later entry to marriage and parenthood, and a prolonged and erratic transition to stable work' (p.8). Debt, poor 
growth in earnings and a significant proportion of income spent on housing costs (Heath \& Calvert, 2013; Intergenerational Commission, 2018) may contribute to increased dependence on family support as an aspect of young people's lives.

Parents appear to be positioned in the White Paper 'Success as a Knowledge Economy: Teaching Excellence, Social Mobility and Student Choice' as having a role in informing students' choices:

Higher education is a life-enriching experience which can positively enhance many different aspects of a person's future - including their future earnings. Faced with such decisions, it is vital that young people and their parents have access to the best possible information to help them make the right choices. (Department for Business, Innovation and Skills, 2016, pages 57-58 para. 41 ).

Our analysis of parents' positioning as a 'stakeholder' group in higher education is preceded by brief examinations of the concepts of 'stakeholder' and 'teaching excellence' in higher education.

Freeman's definition of 'stakeholder' is often-cited: 'all of those groups and individuals that can affect, or are affected by, the accomplishment of organizational purpose.' and, Freeman continues, 'Each of these groups has a stake in the modern corporation, hence, the term, "stakeholder"' (Freeman, 2010:25). Our application of this concept to higher education is informed by the work of Leveille (2006:150) writing in the context of higher education in the United States, pointed to a need for more explanation of who the stakeholders are and their role in higher education. Within 'the higher education stakeholder community' he distinguished between 'stakeholders', 'customers' and 'influencers'. The 'stakeholders' he defined as 'Any person, group, or organization that can place a claim on an organization's attention, direction, or resources. Stakeholders typically include faculty, staff, administrators, policymakers, and major donors' whereas 'customers' are 'Any person who brings dollars or other valued resources into the organization or rely on the product of the organization in the conduct of their own business. Customers include prospective students, current students, donors, alumni and employers.' As 'people who influence the stakeholders or customers', parents are positioned within the 'influencers', who may also be stakeholders or customers (Leveille, 2006:155). Our research suggested that parents can have an important role as influencers when it comes to shaping students' higher education choices and therefore it is important to understand their views about the purposes of higher education, how they judge its quality and to consider what might be the implications of parents' views of higher education purposes and of teaching excellence for universities.

\section{Teaching excellence in higher education}


Ideas about teaching excellence in higher education are heavily influenced in the UK context by the Teaching Excellence and Student Outcomes Framework (TEF) and, as we have argued elsewhere (Wood and Su, 2017), there is a range of different perceptions of what it is and how it may be evidenced. The TEF is a national exercise, which was introduced by the UK government in 2016. It assesses excellence in teaching at universities and colleges, and how well they ensure excellent outcomes for their students in terms of graduate-level employment or further study. Three ratings, Gold, Silver and Bronze, are currently used in the TEF assessment. When the TEF was introduced, the government argued that:

The TEF will provide clear, understandable information to students about where teaching quality is outstanding. It will send powerful signals to prospective students and their future employers, and inform the competitive market. (Department for Business, Innovation and Skills, 2016, page 13 para.26).

The concept of teaching excellence is often problematic and contested:

Concepts of excellence, like concepts of quality, are subject to debate. How excellence is defined, operationalised, and measured in relation to teaching and learning still lacks a clear consensus. (Gunn \& Fisk, 2013:9).

Our previous research into academics' perspectives on teaching excellence suggested a concern to retain a focus on the pedagogical relationship at the heart of learning and teaching in a discourse dominated by outcomes and measures (Wood and Su, 2017). Performative interpretations of teaching excellence provide a limited view of teaching and Skelton (2007:3) has argued for recognition of the broader purposes of higher education:

If teaching excellence is to become a meaningful concept in our lives it has to look beyond current preoccupations with the economy, efficiency and effectiveness - in common parlance 'what works'. It also has to look beyond interpersonal relations to examine the broader purposes it might serve as higher education seeks to make a full and valued contribution to wider society.

The broader purposes and importance of universities today cannot be defined solely in terms of the outcomes and 'instrumental goods' because unlike commercial businesses, 'most of the important goals of a university are not quantitative, they can't be measured; they will need ... to be judged.' (Collini, 2012:138).

In his discussion of the public/private distinction in higher education, Marginson (2018: 323-324) has argued that in higher education: 
Anglo-American policy focuses on the private benefits for students/graduates, principally higher earnings, and on their individual choices and customer satisfaction. The emphasis on private benefits, consistent with the marketing ethos that has gripped many HEls, is used to justify tuition regimes. The public dimension is defined narrowly in terms of a market economy in which individual benefits are paramount.

Parents may hope that private benefits such as employment prospects and earnings potential for their children will be enhanced through gaining a degree. A desire for higher education to develop a broader outlook on the world and to enable students to make 'a full and valued contribution to wider society' (Skelton, 2007:3) can co-exist with this but appears to be located within a discourse which is less individualistic and more aligned to the purpose of citizenship, society and the common good.

Many researchers have identified some possible unintended consequences of marketisation of higher education for student learning and pedagogic relationships between academics and students. Based on their empirical study, Bunce et al. (2017:1973) suggest a negative relationship between a consumer orientation and academic performance. On the pedagogic relationship, Nixon et al. (2018:927) suggest that:

market ideology in a higher education context amplifies the expression of deeper narcissistic desires and aggressive instincts that appear to underpin some of the student 'satisfaction' and 'dissatisfaction' so crucial to the contemporary marketized higher education institution.

The findings of our previous research demonstrated a range of understandings, meanings and emphases from academics in their responses to the question of what constitutes excellence. For some, excellence seemed to refer primarily to pedagogic competence and skills. For others it embraced research-informed pedagogic practice. Further factors identified as important included the relationship with the students, the teacher's influence on them and subject knowledge. The research participants recognised limitations inherent in the discourse of 'excellence' and that the term is open to myriad interpretations and understandings. Unsurprisingly perhaps, views of measurability appeared to be dependent on the definitions and interpretations of excellence. To many participants, excellence was almost impossible to 'measure'. The TEF was perceived by some participants as 'problematic' and as something that could, potentially, reduce teaching excellence to an evidence-gathering process. The research findings suggested the need for a more nuanced, inclusive interpretation of teaching excellence which recognises the conjoined nature of teaching and research in higher education, and which also rebalances a focus on outcome-related measures with understandings of purposes and the development of the processes of learning. 
Our earlier study on students' perspectives on teaching excellence indicated that students tended to relate teaching excellence to their personal experience of quality teaching, and the attributes of a 'good' university lecturer (Su and Wood, 2012). Our study suggested that students perceived it to be a combination of the lecturer's subject knowledge, willingness to help and inspirational teaching methods that made a 'good' university lecturer. In addition, being humorous and able to provide speedy feedback were also perceived to be important factors. Our study also demonstrated that the definitions of teaching excellence cannot be obtained adequately from typologies and descriptions of techniques and skills. What emerged was that conceptualisations of teaching excellence appear richer and more meaningful when established through dialogue with students as respected co-constructors of knowledge.

Whilst different 'stakeholder' groups emphasised particular aspects of teaching excellence, there appeared to be commonality too in the significance attributed to factors such as pedagogical relationships, knowledge, expertise and pedagogic skills of the lecturer. There was a measure of agreement, (as will be evident too in the parent respondents' views in the research which informs subsequent sections of this paper) that not all aspects of teaching excellence can be evidenced through metrics.

\section{The study}

The study reported here was a qualitative research study using an interpretative approach through which we aimed to develop an understanding of parents' perspectives as higher education 'stakeholders'. This study drew on empirical data gathered via focus group interviews and an online survey with 24 participants. The same questions were asked of all participants. The methods were complementary, for the online survey allowed access to a wider group of respondents whereas the semi-structured focus groups enabled responses to be probed and offered opportunities to gather more in-depth insights. Two focus groups were held in Yorkshire and Merseyside with 8 participants, and 16 participants responded to the online survey. Each focus group interview lasted up to an hour and each was transcribed afterwards. In the focus group interviews and the online survey, participants were asked to share: their perceptions of the role and value of higher education for their children; their role and involvement in the decision-making process in their child's choice of university; whether the concept of 'stakeholder' was one with which they would identify as parents; and their understanding of 'teaching excellence' and whether this could be measured.

The participants were from different backgrounds in relation to their employment status and their education levels. Participants were from the following geographical locations in the UK: Greater Manchester, Merseyside, Yorkshire, Cumbria, Northern Ireland, and Cleveland. The majority of the participants $(n=20)$ were female, many participants $(n=21)$ had university level education themselves, and almost all of them 
$(n=23)$ were in professional career positions. The authors make no claim that this sample is representative of all parents. This was a non-probability sample which included snowball sampling and convenience sampling. Some of the shortcomings of a convenience sample as 'one that is simply available to the researcher by virtue of its accessibility' (Bryman, 2008:183) were compensated for to some extent, through the combination with snowball sampling where 'the researcher makes initial contact with a small group of people who are relevant to the research topic and then uses these to establish contacts with others' (Bryman, 2008:184). Participants were invited to recommend others with children of university age to contribute their views. As such we were able to access the views and experiences of a sample of participants in relation to the purposes of this study.

Newby (2014:60) maintains that the choice of sampling method should be 'the method that gives us the best results for the circumstances of our research'. With this sampling strategy it would be unwise to suggest our findings are definitive and we recognise that the benefits of accessibility must be weighed against the shortcomings of unrepresentativeness. However, the data have generated interesting findings which may serve as 'a springboard for further research or allow links to be forged with existing findings in an area' (Bryman, 2008:183). We have begun to do the latter through the discussion in this paper which is informed by literature in the field. Regarding the former, avenues for follow-on research which suggest themselves from this study are identified in the conclusion.

\section{Findings}

In the discussion of the findings, a coding system was devised in order to safeguard anonymity of the respondents who are therefore identified only in terms of their general geographical location and basic information about their children. Each participant also has a letter identifier to allow data to be attributed to individuals for example 'Participant R1, who has a child studying at university'.

\section{The idea of parents as a 'stakeholder' group}

The majority of research participants believed that parents should be treated as an important stakeholder group for various reasons. One was because their children's education is at stake and another that they are funding their children's university education by paying some of the costs of it.

I think particularly in the current climate where there is such a financial commitment. Certainly, we would have a major contribution to that financial cost if my son goes to university. So immediately we're stakeholders. (Participant R17, who has two sons studying at school)

Some participants also noted that the 'stake' has emotional and financial dimensions. 
It is important that whilst the student develops a sense of adult responsibility, the relationship with the parents must remain positive and supportive in order for the student to gain the maximum from a university education. This support comes in many forms including financial and emotional. (Participant R3, who has a daughter currently studying at university)

Many participants expressed dissatisfaction with how universities engage with them currently as a stakeholder group, perceiving there to be a huge difference between how schools and universities engaged with parents. It appeared to them that universities tend to engage parents only at open or applicant days when their children choose their degree study, and at the graduation ceremony when their children have completed their degrees.

It would be useful to have the option of discussing the course with parents during the time the students are there. This should be voluntary and agreed by the student that their parents should be involved. So many times I have only met the lecturers at the degree ceremony. (Participant R14, who has two children recently having completed university degree courses and two who are currently at university)

It appeared that respondents influenced their children's decision-making to varying extents. Typically, they were involved in decision-making, guiding this process for example through research and information-gathering. One participant told us:

I leave it up to my children - I guide them, I make sure they've researched it properly and then I help them with their decisions (Participant R22, who has two children, one currently at university and one at school)

Another made a link between their interest in decision-making and their investment:

It's a big investment for parents now, as well. So, you are going to have more of an interest because we've invested enough. (Participant R23, who has three children and two currently at university)

Another shared more detail about the part they had played in deciding to which universities applications would be made:

I sat with all of them and it was about, what subject to you want to study? And we started at it from that angle and then we talked about geography I had one son who was really keen to look at the Times and the listings and all of that and was really swayed by that... at the end of the day it was about, what do you want to do? Where do you want to do it? And that 
instantly narrowed it down. You know, if they wanted to do geography and wanted to live in the north of England it left us with five to choose from. So, I put those four or five down. And then we drilled down to look at courses but they did it more than me, really. (Participant R24, who has three children, two who have completed university and one currently at university).

There was also some evidence of tensions experienced when parents tried to reconcile their impressions of the suitability of a particular university if these differed from those of their child:

I want him to be happy. I wanted him to choose the university that he felt comfortable with... And yeah, you stand there and you go around these open days and you're thinking, you're not coming here and then you're thinking, what if he chooses to come here? (Participant R18, who has a son studying at university)

At the same time, almost all participants were cautious about the extent to which they should be directly involved as a stakeholder group, in their children's university study. They viewed university study as a transition phase, as their children move into adulthood and during this time they, rather than their parents, should be given independence and responsibility for their own study. A difficulty with this though was that during this transition, the participants did not consider their children to be fully independent adults both in financial and emotional terms.

Some participants suggested they would welcome some university engagement with parents during their children's university study and some specific suggestions were made as to what forms this might take. These included the possible use of parents' newsletters, having parent representatives on university governing councils, having a dedicated personal tutor to speak to regarding their children's general wellbeing and general performance.

An information sheet for parents at the beginning of each year saying what was happening that year in terms of subjects, assessments, course dates, exam dates etc. Not just for information but also to check that the student is keeping up and putting work in on time. This didn't happen with my second son and he lost valuable marks as he hadn't realised an online test had to be done by a certain date. If I had known about it, I could have reminded him. (Participant R14, who has two children recently having completed university and two currently at university)

Some participants went further by suggesting that there should be a parent stakeholder group at each university, and that representatives of parents should sit on the university governing boards. 
It should be noted that a minority of participants $(n=3)$ did not consider parents to be university stakeholders. They expressed the view that parents should not be involved formally at all as this conflicted with their belief that universities are for adults and that their children, as young adults, should be respected in such a way.

\section{The main purposes and value of higher education as perceived by parents}

In the responses to questions of the purposes and value of higher education, three broad interconnected aspects were apparent: academic and social development; employability and career prospects; and intellectual curiosity and self-formation.

In relation to the first, most participants believed university to be a safe space for their children to develop and grow to become well-rounded, both academically and socially. They wanted their children to experience university and all the opportunities they felt it can offer.

Gaining self-confidence and moving out into a wider world of people from different backgrounds; becoming interested and engaged in the knowledge and skills associated with their chosen pathway; gaining a clearer sense of how they want to carry their skills and capabilities though into the world of work. (Participant R7, who has two children recently having completed university study and one who is currently at university)

I have a strong belief that higher education is an end in itself - that studying for a degree is valuable because it allows you to think, explore, broaden your horizons, develop 'soft' skills such as critical thinking, teamwork, how to be independent. It exposes you to ideas and perspectives you may not have experienced before. (Participant R6, who has one child is at school)

In relation to employability and career prospects, these emerged as important issues during the participants' deliberations over the purposes and value of higher education.

A university degree is essential for many professions today. A university education would prepare my son well for his intended future career as it's a huge investment for him and the family both emotionally and financially. (Participant R1, who has a child currently at university)

In relation to intellectual curiosity and self-formation, for some participants priority was given to university as a formative experience. 
I agree with what people have said about universities being a wonderful place of formation as well as a place of learning. What I also sort of see as a very different kind of learning experience than you get from secondary school. My hope is that my daughter will gain that love of intellectual curiosity and so I think the idea of independent intellectual pursuit, which university does encourage. For me, it's also about social skills, the whole formation of yourself as an independent young adult. (Participant R21, who has a daughter studying at university).

The priority and ranking of these purposes were different for each participant as they argued that this would be related to their families' socio-economic backgrounds, social class and their prior education level. In addition, the value of higher education would also be different depending on their children's interests and expectations.

\section{Parents' perspectives on teaching excellence}

Views expressed related broadly to the design of relevant degree courses, the delivery of these courses and the support for students and their learning.

In relating the idea of teaching excellence to the design and delivery of the degree, many participants reported that they expect academics to be 'experts' in the subject they teach, to be passionate about their subjects, and able to excite and engage students. For some participants, their children's relations with academics were a key element of teaching excellence, believing teaching excellence to be evident when academics recognise individual students' needs and support them accordingly.

I think 'teaching excellence' should be about two things - one is to do with the relevance of the degree programme; another one is how staff deliver the programme, for example, are they passionate about the subjects and are they caring about the students they teach. (Participant R1, who has a child currently at university)

When asked about the measurability of teaching excellence, most participants expressed the view that teaching excellence should be measured, and various indicators were suggested.

I think teaching excellence is about both the quality of lectures, but also the quality of seminars and tutorials. It is also about being available for students who may have questions. It should be measured by observation, auditing marking, availability of lecture notes, speed of marking, and the attitude of lecturers, i.e. showing a commitment to teaching over research. (Participant R10, who has one child currently at university and another one at school) 
I think 'teaching excellence' relates to a number of indicators (e.g. contact hours, employability etc). I would like it to relate more to outcomes (has the student made the progress expected?), and student voice, and perhaps through qualitative measures (e.g. observation, work scrutiny). (Participant R6, who has one child at school)

At the same time, some parents raised concerns about measuring of teaching excellence, believing that the judgement of this is not always amenable to measurement on a predetermined scale as currently used in TEF.

I'm not sure it can be measured in a way that gets to the essence, but it should not be measured by simple metrics and/or data just because it can be easily collected. The views of teachers and students of the experience and their reflections on it are part of the evidence but not in ways that reduce evidence collection to simple surveys of whether the teaching was enjoyable or not. (Participant R13, who has one child recently having completed university study and another one who is currently at university)

\section{Discussion: parents as non-typical stakeholders}

Knowing who the stakeholders involved in higher education are may be considered important in lending competitive advantages and as a 'fundamental step' towards identifying their needs and how these might be met (Mainardes et.al. 2010:77). The term 'stakeholder' may also suggest a primary focus on individuals, each with their own business stake in higher education primarily as a financial investment, in contrast to the centrality of a relationship with people, based on commitment to the broader purposes and value of higher education and learning. Our respondents saw their 'stake' in terms of a financial commitment but also, as parents they had an important stake in their children's well-being and happiness.

Universities serve different 'constituencies' or communities, each with their own interests in higher education (see Leveille, 2006). However, there can be tensions for universities to navigate in promoting student independence as adults and their agency and development through higher education to become autonomous critical beings, whilst at the same time mindful of the constituency of parents as 'influencers' who have their own expectations of university education and conceptions of excellent teaching. There was some ambivalence amongst the parents themselves as to the legitimacy of their engagement in their children's university education, recognising that during this time the young person gradually becomes independent and therefore may benefit from the support of their parents not only financially but also in emotional support. Therefore to enable them to do this, an argument was made by our respondents for universities to engage with parents, although at the same time there was evidence of some conflict for parents in reconciling this position 
with a desire to give their children the freedom and space to live and grow as independent young adults.

Tensions, contradictions and challenges for parents emerged in this study for example in reconciling the co-existence of their desire to be involved and engaged with scope for students to be formed as independent young adults. The idea of 'helicoptering' is a term which has been invoked in the literature to refer to 'those who closely monitor their student offspring and who are ready to intervene at any sign of difficulty' (Lewis et al.,2015:417) and for Von Bergen and Bressler (2017:3) it is used to describe 'excessive levels of involvement, advice, problem-solving, control, protection, and abundant and unnecessary tangible assistance in the service of their offspring's well-being.' With reference to higher education in a North American context, Von Bergen and Bressler (2017:4) suggest that 'Helicopter parents seem to maintain continuous contact with their college-aged adult children as well as with the school administration. Cell phones, it seems, have become virtual umbilical cords.' This excessive 'hovering' and over-protection potentially may become a barrier to growth into maturity. When parents expect that universities should adopt the role of protective parenting this may influence students' attitudes and present challenges to the idea of what higher education is:

Some students feel the need to be sheltered from facing intellectual challenges and any conflicting ideas, thoughts, and words despite research showing the value of dissent, not for the truth that it may or may not hold or for its ability to persuade, but rather for the thinking that it generates.' (Von Bergen and Bressler, 2017:5).

Although well-intentioned, parents' desire to promote well-being through 'helicoptering' behaviours may at the same time undermine the value of higher education as expressed by some of the parents in our study. Parents in our study recognised the self-formation of independent young adults and exposure to ideas and perspectives previously not encountered as being a valuable part of higher education whilst also affording value and significance to pedagogical relationships between academics and students which are academically nurturing, understanding and supportive.

Given their role as influencers, we were particularly interested in parents' conceptions of teaching excellence. Their responses indicated a recognition of aspects of this that they felt could be evidenced and quantified and also acknowledgement that some aspects defy measurement, including for example the 'feel' of the institution, openness, the passion conveyed by academics for the subjects taught and whether the institution cares about and supports students' learning needs: 'Once we begin to measure, we begin to tick boxes and then we always, always lose something.' one respondent told us. Their conceptions of how teaching excellence is to be judged ranged from very specific expectations 
expressed as performance measures - contact hours, attendance, programme completion, student feedback and student satisfaction data, research quality, degree results and employability after university, - to more intuitive and affective aspects. It was suggested that the latter should not be overlooked in favour of simple metrics which can be more easily collected and are more amenable to measurement.

Excellent teaching was believed by some parents to be amenable to indicators and measures, for example they cited progress measures, contact hours, speed of return of marked work, graduate employability and so on. As previously explained, there also appeared to be recognition that whilst aspects such as these could be measured according to scales and indicators, there was an important role for individual judgement to be exercised too because some things, for example those that 'get to the essence', may be subjective, specific to particular contexts and also matters of personal interpretation and judgement rather than measurement according to universal scales. Whilst measurement tends to be trusted, judgement may be viewed with some misgivings and:

the trouble is, as l've already insisted, that not everything that counts can be counted. Sometimes we can only know if something is a good example of its kind by the view taken of it in the long term by those competent to judge. (Collini, 2012:139)

Parents' views seemed to reject a rigid vocational / liberal dichotomy in that they wanted university education to be a good preparation for a career whilst also wanting their children to broaden their outlooks, develop intellectual curiosity and independent thought. These two of course are not contradictory and appeared to coexist in their conceptions of teaching excellence. Therefore enhanced employability and career prospects were seen by parents to be important aspects of the value and purposes of higher education which co-existed with a desire for the experience of higher education to develop a broader outlook on life. This expectation of graduate employability raises some dilemmas for universities which are not of their making. In line with a neo-liberalist agenda:

universities are set-up to resemble a market economy, competing against one another for student enrolment and thereby tuition and rankings in accordance with employment outcomes. (Kinash, et al., 2018:303)

Yet whilst they are judged and ranked according to these outcomes, the lack of graduate employment opportunities is impacted by wider factors in the economy and wider trends and changes in society which are not within the remit of universities to control. Kinash, et.al. (2018:303) suggest some critics argue that: 
blame is placed on individuals and institutions when failures are actually due to the tail-end of the global financial crisis and over-enrolment in popular degrees/disciplines (Brown \& Carasso, 2013; McArthur, 2011).

Significant unresolved tensions for parents and universities appear to emerge from this study. Parents appeared to want a continuing role in monitoring their children's well-being and progress, although views about the extent of this differed. Explanations for this may be associated with the concept of 'emerging adulthood' (Arnett, 2015) and perhaps also in parents' awareness that young people may need continued support in becoming adults, seeing this as a journey towards independence, rather than an 'event' whereby 'adulthood', independence and autonomy are gained at the point of entry to university at age eighteen. There was a desire amongst the parents to allow their children to experience higher education as an opportunity to grow into mature, independent adults capable of making their own decisions. There may be tensions though between a desire to support a journey towards independence on the one hand and 'helicoptering' tendencies of some parents referred to in the literature and which may be linked to a desire to minimise exposure to 'risk'. A desire to minimise exposure to risk-taking, for example, to provide shelter from views that may challenge and disturb existing beliefs, may create tensions for universities where the development of critical, mature, adult beings with a capacity for independent thought have an essential place.

A universally agreed definition of teaching excellence is elusive, being dependent on views and beliefs about the purposes of higher education and, how one answers the question 'excellence for what?' (Runté and Runté, 2018:78). The TEF metrics, argue Runté and Runté (2018:77):

are the metrics of a manpower discourse: student employment outcomes; the learning environment measured by manpower-orientated criteria such as the dropout rate; and teaching and assessment measured by criteria such contract hours, course design, and (presumably) student feedback.

Parents' views of teaching excellence appeared to reflect elements of this discourse in their suggestions of specific measures by which judgements of teaching excellence might be made. Amongst the implications of a 'manpower discourse' for academic practice may be 'curriculum-centred course design, based on the skills and knowledge identified as crucial by employers' (77).

\section{Conclusion}

The current level of engagement by universities with parents as 'stakeholders' emerged as unsatisfactory in the view of many of our respondents. The role of parents in higher education may be considered substantively different to their role when their children were at school. However, an argument was suggested for some 
form of continued involvement of parents in higher education because young people move gradually into adulthood and their dependence on parents may be typically over a protracted period. An argument for continuing dialogue with parents during the period of students' study at university therefore appears to commend itself from this research. The role of parents in informing and influencing decision-making when their children were at the stage of choosing a university and a course of study was apparent. However, parents appeared to have little formal contact and to experience a sense of detachment from the university after the initial choice and induction stage and there was some evidence of an appetite for continued engagement with universities in some form.

The research has suggested that there may be scope for further exploration of the implications for universities to develop their engagement with parents as a stakeholder constituency and as a source of support for students as they journey towards independence. If adulthood is conceptualised as a journey rather than an event at age eighteen, then it may be useful to give further thought to the scope for continued dialogue with them during the students' undergraduate studies. Through dialogue with parents and students, more nuanced, balanced interpretations of teaching excellence may also develop which afford importance not solely to outcome-related measures but also to the processes of learning and the wider purposes and value of higher education.

\section{References}

Arnett, J. J. (2015), Emerging Adulthood. (2nd Ed.), Oxford University Press, New York.

Bryman, A. (2008) Social Research Methods. (3rd Ed.), Oxford University Press, Oxford.

Bunce, L., Baird, A. and Jones, S. E. (2017), "The student-as-consumer approach in higher education and its effects on academic performance", Studies in Higher Education, Vol. 42 No.11, pp. 1958-1978.

Collini, S. (2017), Speaking of Universities. Verso, London.

Collini, S. (2012), What Are Universities For? Penguin Books, London.

Department for Business, Innovation and Skills (2016), "Success as a Knowledge Economy: Teaching Excellence, Social Mobility and Student Choice" Cm 9258.,

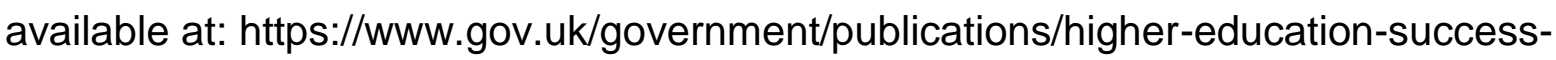
as-a-knowledge-economy-white-paper. (accessed 25 May 2018). 
Department for Business, Innovation and Skills (2011), "Higher Education: Students at the Heart of the System" Cm 8122 available at

https://assets.publishing.service.gov.uk/government/uploads/system/uploads/attach ment data/file/31384/11-944-higher-education-students-at-heart-of-system.pdf (accessed 28 May 2018).

Freeman, R. E. (2010), Strategic Management: A Stakeholder Approach. New York, Cambridge University Press.

Gibran, K. (2016), The Prophet. London, Pan Macmillan.

Gunn, V. and Fisk, A. (2013), Considering teaching excellence in higher education: 2007-2013. A literature review since the CHERI report 2007. York, The Higher Education Academy.

Hazelkorn, E. (2015), Rankings and the Reshaping of Higher Education: The Battle for World-Class Excellence. 2nd Ed. Basingstoke: Palgrave Macmillan.

Heath, S. and Calvert, E. (2013), "Gifts, Loans and Intergenerational Support for Young Adults”, Sociology, Vol 47 No.6, pp.1120-1135.

Intergenerational Commission (2018), "A New Generational Contract. The final report of the Intergenerational Commission", available at https://www.resolutionfoundation.org/app/uploads/2018/05/A-New-GenerationalContract-Full-PDF.pdf (accessed 13 May 2018).

Kinash, S., McGillivray, L. and Crane, L. (2018) "Do university students, alumni, educators and employers link assessment and graduate employability?", Higher Education Research and Development, Vol. 37 No. 2, pp. 301-315.

Leveille, D.E. (2006), "Accountability in Higher Education: A Public Agenda for Trust and Cultural Change", Research and Occasional Papers Series. University of California Center for Studies in Higher Education, Berkeley, available at: https://escholarship.org/content/qt38x683z5/qt38x683z5.pdf (accessed 13 May 2018).

Lewis, J., West, A., Roberts, J. and Noden, P. (2015), "Parents' involvement and university students' independence", Families, Relationships and Societies, Vol. 4 No.3, pp. 417-432.

Magalhães, A., Veiga, A. \& Amaral, A. (2018), "The changing role of external stakeholders: from imaginary friends to effective actors or non-interfering friends", Studies in Higher Education, Vol. 43 No.4, pp. 737-753. 
Mainardes, E. W., Alves, H. and Raposo, M. (2010), "An Exploratory Research on the Stakeholders of a University", Journal of Management and Strategy. Vol.1 No.1, pp.76-88.

Marginson, S. (2018), "Public/private in higher education: a synthesis of economic and political approaches", Studies in Higher Education, Vol. 43 No. 2, pp. 322-337.

Newby, P. (2014), Research Methods for Education. 2nd ed. Abingdon, Routledge.

Nixon, E., Scullion, R. and Hearn, R. (2018), "Her majesty the student: marketised higher education and the narcissistic (dis)satisfactions of the student-consumer", Studies in Higher Education, Vol. 43 No.6, pp. 927-943.

Runté, M. and Runté, R. (2018), "Excellence For What? Policy Development and the Discourse on the Purpose of Higher Education" in Broughan, C., Steventon, G. \& Clouder, L. (eds) Global Perspectives on Teaching Excellence: A New Era for Higher Education. Abingdon, Routledge.

Skelton, A. (2007), "Introduction" in Skelton, A. (Ed), International Perspectives on Teaching Excellence in Higher Education: Improving Knowledge and Practice. Abingdon, Routledge.

Su, F. and Wood, M. (2012), "What makes a good university lecturer? Students' perceptions of teaching excellence", Journal of Applied Research in Higher Education, Vol. 4 No.2, pp.142-155.

Universities and Colleges Admissions Service (2018) "Parent Guide 2018. Everything you need to support your child with their higher education choices" available at https://www.ucas.com/file/101806/download?token=2DHk4PXV (accessed 28 May 2018).

Von Bergen, C.W. and Bressler, M.S. (2017), "The counterproductive effects of helicopter universities", Research in Higher Education Journal, Vol 33, pp.1-17.

Wood, M. and Su, F. (2017) 'What makes an excellent lecturer? Academics' perspectives on the discourse of 'teaching excellence' in higher education", Teaching in Higher Education, Vol. 22 No. 4, pp. 451-466. 